\title{
Ertapebem disk performance to predict Klebsiella pneumoniae carbapenemase produced by Gram-negative bacilli isolated in a São Paulo city public hospital
}

\author{
Desempenho do disco de ertapenem como preditor da produção de Klebsiella pneumoniae \\ carbapenemase por bacilos Gram-negativos isolados de culturas em um \\ hospital municipal de São Paulo
}

\author{
Lais Pinto de Almeida ${ }^{1}$, Fabiana Puerro de Carvalho², Alexandre Gimenes Marques ${ }^{1}$, Andrea dos Santos Pereira ${ }^{1}$, \\ Renata Puzzo Bortoleto' ${ }^{2}$ Marinês Dalla Valle Martino ${ }^{1}$
}

\begin{abstract}
Objective: To evaluate ertapenem disk performance to predict Klebsiella pneumonie carbapenemase production by Gram-negative bacilli. Methods: All Gram-negative bacilli isolated between January 2010 and June 2011 were tested by disk diffusion (Oxoid ${ }^{\mathrm{TM}}$ ) for sensitivity to ertapenem, meropenem and imipenem. Resistant or intermediate sensitivity strains (diameter $\leq 22 \mathrm{~mm}$ for ertapenem) were also tested for the blaкрс gene by polymerase chain reaction. Disk predictive positive value for Klebsiella pneumoniae carbapenemase and specificity were calculated. Results: Out of the 21839 cultures performed, 3010 (13.78\%) were positive, and Gram-negative bacilli were isolated in $708(23.52 \%)$ of them. Zone of inhibition diameter for ertapenem disk was $\leq 22 \mathrm{~mm}$ for 111 isolates, representing $15.7 \%$ of all Gram-negative isolates. The PCR assay for blaкрс detected 40 Klebsiella pneumoniae carbapenemase-producing strains. No strains intermediate or resistant to meropenem and imipenem were sensitive to ertapenem. The ertapenem disk presented a positive predictive value of $36 \%$ to predict blakpc and $89 \%$ specificity. Conclusion: The resistance of Gram-negative bacilli detected by disk diffusion against ertapenem does not predict Klebsiella pneumoniae carbapenemase production. Other mechanisms, such as production of other betalactamases and porin loss, may be implicated. The need to confirm the presence of the blakp is suggested. Therefore, ertapenem was a weak predictor for discriminating strains that produce Klebsiella pneumoniae carbapenemase.
\end{abstract}

Keywords: Klebsiella; Carbapenems; Drug resistance, multiple, bacterial

\section{RESUMO}

Objetivo: Avaliar o desempenho do disco de ertapenem para predizer micro-organismos produtores de Klebsiella pneumoniae carbapenemase. Métodos: Bacilos Gram-negativos isolados em cultura entre janeiro de 2010 e junho de 2011 foram testados por disco-difusão $\left(0 x\right.$ oid $\left.^{T M}\right)$ para ertapenem, meropenem e imipenem. As cepas consideradas intermediárias ou resistentes (halo $\leq 22 \mathrm{~mm}$ ) para ertapenem foram encaminhadas para a pesquisa do blakpc por reação em cadeia da polimerase. Calcularam-se o valor preditivo positivo e a especificidade do disco. Resultados: Foram realizadas 21.839 culturas nesse período, sendo $3.010(13,78 \%)$ positivas. Bacilos Gram-negativos foram isolados em $708(23,52 \%)$ destas. A zona de inibição do disco de ertapenem foi $\leq 22 \mathrm{~mm}$ para $111(15,67 \%)$ dos isolados. A pesquisa do blaкрс caracterizou 40 cepas produtoras de Klebsiella peneumoniae carbapenemase. Não houve nenhum caso de disco intermediário ou resistente para meropenem ou imipenem com ertapenem sensível. 0 valor preditivo positivo foi de $36 \%$ e a especificidade calculada do disco de ertapenem para produção de Klebsiella pneumoniae carbapenemase foi de $89 \%$ em nosso serviço. Conclusão: A resistência ao disco de ertapenem não define bacilo produtor de Klebsiella pneumoniae carbapenemase. Mecanismos, como produção de outras betalactamases e perda de porinas, podem estar implicados. Sugerese a necessidade da confirmação da presença do gene blakpc. 0 ertapenem, portanto, mostrou-se fraco preditor para discriminar cepas produtoras de Klebsiella pneumoniae carbapenemase.

Descritores: Klebsiella; Carbapenêmicos; Farmacorresistência bacteriana múltipla

\footnotetext{
Study carried out Hospital Municipal Dr. Moysés Deustch - M'boi Mirim, São Paulo (SP), Brazil; Hospital Israelita Albert Einstein - HIAE, São Paulo (SP), Brazil.

${ }^{1}$ Hospital Israelita Albert Einstein - HIAE, São Paulo (SP), Brazil.

${ }^{2}$ Hospital Municipal Dr. Moysés Deustch - M'boi Mirim, São Paulo (SP), Brazil.

Corresponding author: Lais Pinto de Almeida - Avenida Albert Einstein, $627 / 701$ - Morumbi - Zip code: 05652-000 - São Paulo (SP), Brazil - Phone: (55 11) 2151-2530 - E-mail: laispinto@yahoo.com.br

Received on: July 5, 2012 - Accepted on: Oct 25, 2012

Conflict of interest: none.
} 


\section{INTRODUCTION}

Ertapenem (ERT) is a beta-methyl-carbapenem that is active against Gram-negative bacteria producing extended-spectrum beta-lactamases (ESBL) or AmpC, and it is widely used in clinical practice since 2001. In the United States, the emergence of resistance against carbapenems is usually related to the production of carbapenemases, such as metallo-beta-lactamases and Klebsiella pneumoniae carbapenemase (KPC). However, other mechanisms may be involved in the resistance to this antibiotic class, including porin loss associated with ESBL or AmpC ${ }^{(1)}$ production.

KPC is a class-A carbapenamase that inactivates all beta-lactam antibiotics. It was first described in Klebsiella pneumonia, but it has also been occasionally detected in other enterobacteria. This enzyme is coded by sequences related to transposons and are present in conjugative plasmids with high dissemination power ${ }^{(2)}$.

The identification of KPC-producing Gram-negative bacilli (GNB) is mandatory, as they may cause severe infections, and carbapenems (imipenem - IMP and meropenem - MER) are the therapy of choice in many nosocomial infections. In addition, the identification of carrier individuals allows controlling the dissemination of those agents. No precise phenotypic tool for their identification has yet been described, and the available tools are not able to differentiate resistance mechanisms $\mathrm{s}^{(3,4)}$.

The Brazilian Health Surveillance Agency (ANVISA) currently recommends disk-diffusion with carbapenems for screening and determination of minimum inhibitory concentrations (MIC), followed by confirmation using molecular biology to identify the gene $b l a \mathrm{KPC}^{(5)}$.The ERT disc is considered a very sensitive marker, but data published in Brazilian and international literature on its specificity are still subjective and conflicting ${ }^{(6-8)}$.

\section{OBJECTIVES}

To evaluate the positive predictive value and the specificity of the ertapenem disk to predict the presence of KPC-producing Gram-negative bacilli.

\section{METHODS}

Gram-negative bacilli (GNBs) isolated in biological material cultures collected and processed at Hospital Municipal Dr. Moiysés Deautch, in M’Boi Mirim, SP, Brazil, between January 2010 and June 2011, were tested by disk-diffusion $\left(\right.$ Oxoid $^{\mathrm{TM}}$ ) for ERT, MER, and IMP in Mueller-Hinton agar (BioMérieux ${ }^{\circledR}$ ). The interpretation criteria applied were those suggested in the Technical Note published by ANVISA in 2010.
The strains that were considered intermediate or resistant to ERT (zone of inhibition diameter $\leq 22 \mathrm{~mm}$ ), MER (zone of inhibition diameter $\leq 20 \mathrm{~mm}$ ) or IMP (zone of inhibition diameter $\leq 20 \mathrm{~mm}$ ) were submitted to bla $\mathrm{KPC}$ detection by polymerase chain reaction (PCR). DNA was extracted as previously described. Direct primer 5'TCGCTAACTCGAACAGG3' and reverse primer 5’TTACTGCCCGTTGACGCCCAATCC 3’ were used for amplification.

ERT disk positive predictive value (PPV) and specificity were calculated. PPV was calculated based on the true positive (TP)/TP+false positive (FP) ratio, where TP represents the strains positive for the bla $\mathrm{KPC}$ gene and FP the number of ERT-resistant strains, but with negative PCR results. Assuming 100\% ERT sensitivity, specificity was calculated by the $\mathrm{d} / \mathrm{b}+\mathrm{d}$ ratio, where " $\mathrm{d}$ " represents the ERT-sensitive strains, and "b" the ERTresistant or intermediate strains negative for bla $\mathrm{KPC}_{\text {. }}$

\section{RESULTS}

Out of a total of 21839 cultures from different biological materials performed during that period, 3010 (13.78\%) were tested positive, with GNB isolated in $708(23.52 \%)$ of these positive cultures.

ERT disk zone of inhibition was $\leq 22 \mathrm{~mm}$ in 111 $(15.67 \%)$ of the isolates, out of which $96(86.48 \%)$ were considered resistant and $15(13.51 \%)$ intermediate. Strains were submitted to molecular testing.

The bla $a_{\mathrm{KPC}}$ gene tests characterized $40 \mathrm{KPC}$-producing strains. Klebsiella pneumoniae was biochemically identified in 38 cases and Enterobacter cloacae in 2 cases. The bacteria were isolated in the urine in 16 cases, rectal/ anal swab in 17 cases, tracheal secretion in 4 cases, blood in 2 cases and pancreatic abscess in one case. Eleven of the infected patients died. In all genepositive cases, the zone of inhibition diameter of the ERT disk was considered resistant. No MER or IMP intermediate or resistant samples were sensitive to ERT.

The results showed that there were 40 bla $\mathrm{KPC}^{-}$ positive strains out of the 111 strains found to be resistant or intermediate to ERT among 708 isolated GNB. Calculated ERT disk PPV and specificity for KPC production were $36 \%$ and $89 \%$, respectively.

\section{DISCUSSION}

The study of Anderson et al. ${ }^{(7)}$, considering the potential clinical impact, stresses the importance of evaluating the sensitivity to ERT because this is the most sensitive indicator of KPC, independently of the method applied. 
However, Woodford et al. ${ }^{(8)}$ mentioned that the in-vitro resistance to that carbapenem is not specific for KPC production, particularly when considering centers where carbapenemase-producing bacteria are rare.

The present study shows objective data on PPV and specificity of the ERT disk to predict KPC in our center. It was observed that ERT-disk resistance does not determine that the isolated GNB produces KPC. Other resistance mechanisms, such as the production of other beta-lactamases and porin loss, may be implicated. Therefore, ERT was a weak predictor for the identification of KPC-producing strains in our cohort.

\section{CONCLUSION}

Despite the efforts to find an ideal phenotypic method to trace KPC production, there are still no results supporting the individual use of these tools. There are many groups working to find better methodologies, but no definite conclusions have been published yet. Consistent with ANVISA guidelines, the data obtained in the present study also indicate the need of confirming the presence of the bla $\mathrm{KPC}_{\mathrm{C}}$ gene to determine KPC production using molecular biology.

\section{REFERENCES}

1. Leavitt A, Chmelnitsky I, Colodner R, Ofek I, Carmeli Y, Navon-Venezia S. Ertapenem resistance among extended-spectrum-beta-lactamase-producing Klebsiella pneumoniae isolates. J Clin Microbiol. 2009;47(4):969-74.

2. Endimiani A, Perez F, Bajaksouzian $S$, Windau AR, Good CE, Choudhary $Y$, et al. Evaluation of Updated Interpretative Criteria for Categorizing Klebsiella pneumoniae with Reduced Carbapenem Susceptibility. J Clin Microbiol. 2010;48(12):4417-25.

3. Pasteran F, Mendez T, Guerriero L, Rapoport M, Corso A. Sensitive screening tests for suspected class A carbapenemase production in species of Enterobacteriaceae. J Clin Microbiol. 2009;47(6):1631-9.

4. Bratu S, Mooty M, Nichani S, Landman D, Gullans C, Pettinato B, et al Emergence of KPC-possessing Klebsiella pneumoniae in Brooklyn, New York: epidemiology and recommendations for detection. Antimicrob Agents Chemother. 2005;49(7):3018-20.

5. Agência Nacional de Vigilância Sanitária (ANVISA). Nota Técnica 1/2010. Medidas para identificação, prevenção e controle de infecções relacionadas à assistência à saúde por microrganismos multirresistentes. 2010 [Internet]. [citado 2012 Jul 5]. Disponível em: http://portal.anvisa.gov.br/wps/content/ Anvisa + Portal/Anvisa/Inicio/Servicos + de + Saude/Assunto + de + Interesse/ Informes +e+Alertas/01 +-+NOTA + TECNICA + GGTES + KPC

6. McGettigan SE, Andreacchio K, Edelstein PH. Specificity of ertapenem susceptibility screening for detection of Klebsiella pneumoniae carbapenemases. J Clin Microbiol. 2009;47(3):785-6.

7. Anderson KF, Lonsway DR, Rasheed JK, Biddle J, Jensen B, McDougal LK, et al. Evaluation of methods to identify the Klebsiella pneumoniae carbapenemase in Enterobacteriaceae. J Clin Microbiol. 2007;45(8):2723-5.

8. Woodford N, Dallow JW, Hill RL, Palepou MF, Pike R, Ward ME, et al. Ertapenem resistance among Klebsiella and Enterobacter submitted in the UK to a reference laboratory. Int J Antimicrob Agents. 2007;29(4):456-9. 